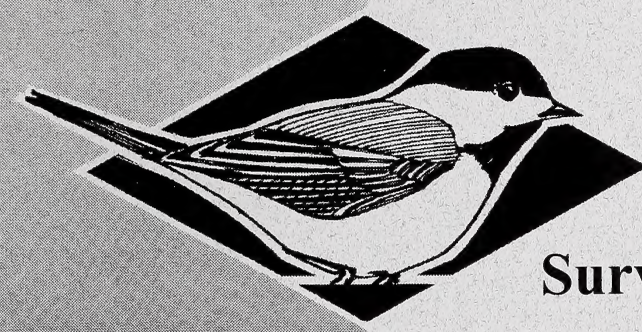
\title{
in the Peace Parkland Region
of Northwestern Alberta - 2001 in the Peace Parkland Region
of Northwestern Alberta - 2001 \\ vey of Native Grassland Butterflies
}

Fish \& Wialife Division

WLDUFE CONSERVATION AND BIODIVERSIT SECTION

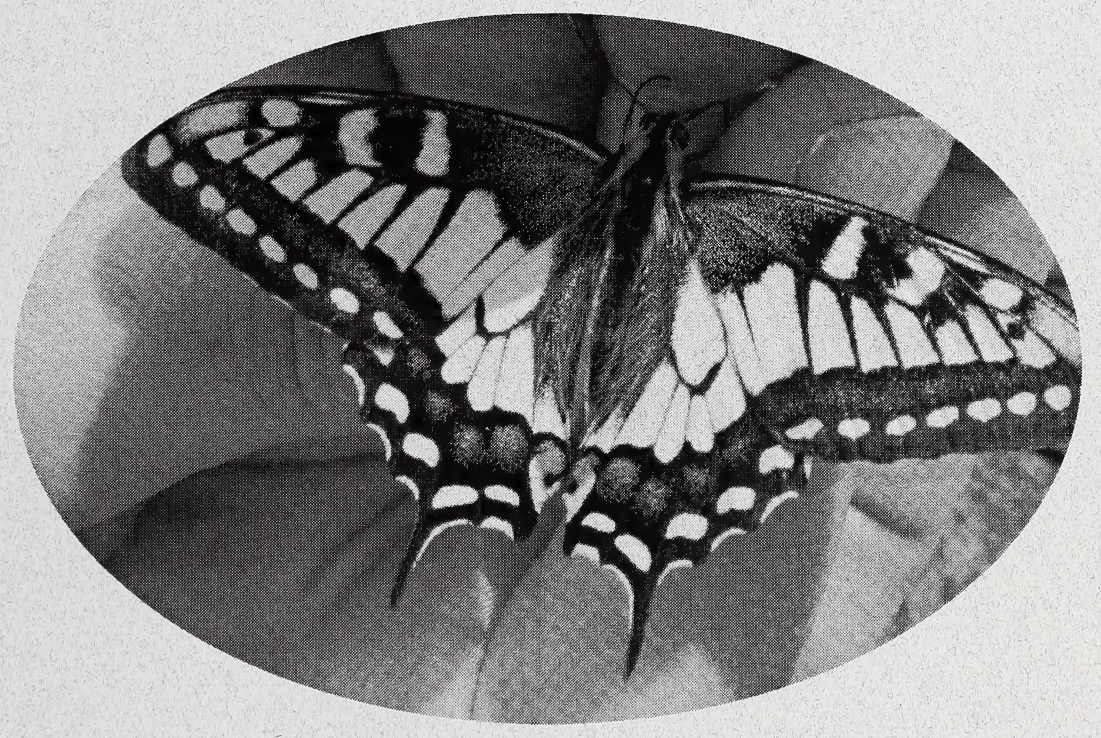

Alberta Species at Risk Report No. 47 



\title{
Survey of Native Grassland Butterflies in the Peace Parkland Region of Northwestern Alberta - 2001
}

\author{
Margot Hervieux
}

Alberta Species at Risk Report No. 47

May 2002

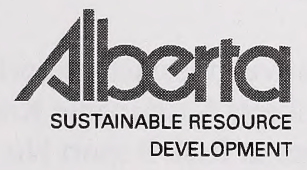


Publication No.: I/068

ISBN: 0-7785-2176-1 (Printed Edition)

ISBN: 0-7785-2177-X (On-line Edition)

ISSN: 1496-7219 (Printed Edition)

ISSN: 1496-7146 (On-line Edition)

Cover photograph: Pike's Old World Swallowtail by Adam James

For copies of this report, contact:

Information Centre - Publications

Alberta Environment / Alberta Sustainable Resource Development Main Floor, Great West Life Building 9920108 Street

Edmonton, Alberta, Canada T5K 2M4

Telephone: (780) 422-2079

\section{OR}

Information Service

Alberta Environment / Alberta Sustainable Resource Development \#100, 311512 Street NE

Calgary, Alberta, Canada T2E 7J2

Telephone: (403) 297-3362

\section{OR}

Visit our web site at:

http://www3.gov.ab.ca/srd/fw/riskspecies/

This publication may be cited as:

Hervieux, M. 2002. Survey of native grassland butterflies in the Peace parkland region of northwestern Alberta - 2001. Alberta Sustainable Resource Development, Fish and Wildlife Division, Alberta Species at Risk Report No. 47. Edmonton, AB. 19pp. 


\section{DISCLAIMER}

The views and opinions expressed are those of the author and do not necessarily represent the policies or positions of the Department or the Alberta Government. 
1.0 INTRODUCTION

2.0 METHODS 3

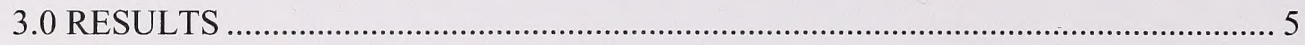

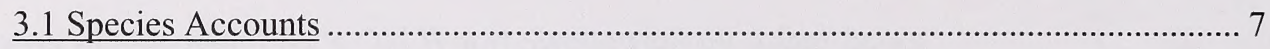

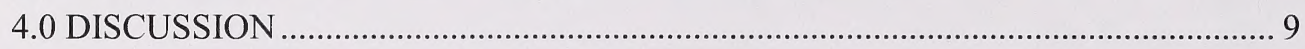

4.1 Species Specific Management Considerations ……................................................ 11

5.0 MANAGEMENT IMPLICATIONS AND FUTURE DIRECTION .......................... 13

5.1 Habitat Protection ............................................................................................. 13

5.2 Further Assessment of the Abundance and Distribution of Disjunct Butterflies

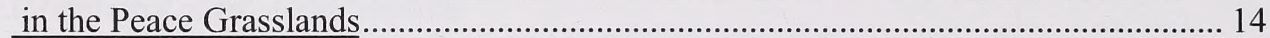

5.3 Clarification of Taxonomy............................................................................. 15

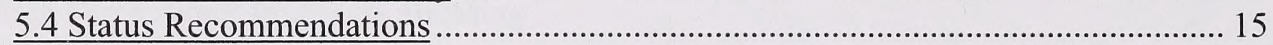

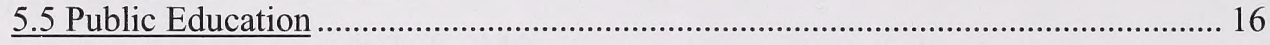

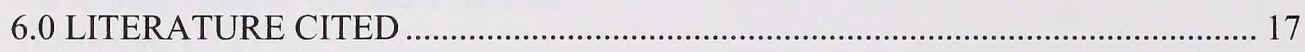

APPENDIX A. PROPOSED METHODS FOR FIXED TRANSECT MONITORING . 19 


\section{LIST OF FIGURES}

Figure 1. Map of historical and new records for south Peace disjunct butterflies............. 4

Figure 2. Flight times for Peace Region disjunct butterflies. ............................................. 7

\section{LIST OF TABLES}

Table 1. Survey locations and butterfly occurrence results by species. 


\section{ACKNOWLEDGEMENTS}

Thanks to Dr. Felix Sperling, Norbert Kondla, Wayne Nordstrom, Dr. Ted Pike and Dr. Charley Bird for providing valuable information and advice. The survey would have been much more difficult without the historical records provided by the Alberta Natural Heritage Information Centre. Survey assistance from Annette Baker and Darcy Meyers (Peace Native Grassland Project), Tara Szkorupa and Adam James (Alberta Fish and Wildlife), Ed Kolodychuk (Alberta Conservation Association), and Helene Walsh and Janina Carlstad (Peace Parkland Naturalists) was most appreciated. 


\section{EXECUTIVE SUMMARY}

The purpose of this study was to assess the current distribution and abundance of eight disjunct butterfly populations or sub-species that are closely associated with the remnant native grasslands of the Peace River Parkland natural sub-region of northwestern Alberta. These grasslands are restricted to the slopes of the Peace River and adjoining tributaries as well as to upland fragments which currently represent less than $0.5 \%$ of the original native grassland land base. Three of these butterflies are listed as provincially "sensitive" by Alberta Fish and Wildlife but taxonomic differences between Peace region and southern populations of these species, as well as serious habitat pressure, point to a need for more detailed population assessment. Very few butterfly records have been collected in the Peace region since the early 1980s and historical records for most of the disjunct butterflies are limited. Since butterflies are closely tied to larval food plants and other habitat features, population health can also be an important indicator of ecosystem health.

The plains skipper, Pike's Old World swallowtail, coral hairstreak, striped hairstreak, Gorgone checkerspot, northern checkerspot, Uhler's arctic and Alberta arctic were chosen for this year's survey based on preliminary general status assessments and recommendations from primary researchers. Historical sites, located along the Peace River and adjoining tributaries from the British Columbia border to the town of Peace River, were visited as well as new sites containing suitable native grassland habitat. There were also upland sites in the Fairview area and east of Grande Prairie. Observers walked each area and recorded all butterflies seen as well as weather conditions and total survey time.

Between June $8^{\text {th }}$ and August $22^{\text {nd }}, 2001,26$ sites were visited at least once. Ten out of 28 historical sites were visited and 16 new sites were identified. All of the surveyed populations except the plains skipper and the coral hairstreak were restricted to native grassland slopes along the Peace and Smoky Rivers, along associated tributaries such as the Clear River and Hines Creek and on the eroded areas of Kleskun Hill. The plains skipper and the coral hairstreak were also found in upland areas of native grassland as well as on gently sloping native hillsides.

The disjunct butterfly populations of the Peace region show a close affinity to native grassland habitats. This is primarily due to their dependence on specific larval host plants as well as their requirements for nectaring and mate-finding sites. Colonization of new and former habitat fragments is likely dependent on the size of the fragments and their distance from the population core. Butterfly populations fluctuate considerably from year to year and this has implications for long term management. Very little native grassland in the Peace region has been protected and there are no standardized management practices for native rangelands under provincial jurisdiction.

Initial findings from this survey indicate the need for enhanced land management and habitat protection strategies; the implementation of annual transect surveying; clarification of the taxonomy for the Peace region populations; and development of public education initiatives including support for existing landowner habitat stewardship programs. 
Digitized by the Internet Archive in 2016

https://archive.org/details/surveyofnativegro0herv_0 


\subsection{INTRODUCTION}

The purpose of this study was to assess the current distribution and abundance of eight disjunct butterfly populations that are closely associated with the native grasslands of the Peace River Parkland natural sub-region of northwestern Alberta and to make recommendations for further monitoring and management. No other region of northern Alberta has such a high diversity of butterflies or as many species (23) with disjunct or edge-of-range populations (Kondla et al. 1994). The disjunct butterfly populations of the Peace region are dependent on grasslands that expanded into the area following the last ice age. During that time, North America experienced a major warming trend (hypsithermal) that lasted until about 6000 years ago. When the climate cooled again, the Peace grasslands and their associated flora and fauna became isolated by $400 \mathrm{~km}$ of boreal forest (Bird et al. 1995).

Historical estimates of the size of the upland native prairie in the Peace region range from 434,500 to $1,129,000$ hectares (Wilkinson 1981). Agricultural expansion since the early 1900 s, however, has confined most of the remaining grasslands to the slopes of the Peace River and adjoining tributaries, and to the Kleskun Hills east of Grande Prairie. The once contiguous upland grassland habitat has been reduced to remnants representing less than $0.5 \%$ of the original area (A. Baker, Peace Native Grassland Program, pers. comm.). The Peace Native Grassland Program (Alberta Conservation Association and Alberta Fish and Wildlife Division) is currently searching for additional upland fragments. In a pilot area around Grande Prairie only about 500 hectares, with parcels ranging in size from 0.03 to 36.42 hectares, have been found to date and most of those sites are within the Kleskun Hills.

Few surveys have been conducted to assess the distribution and abundance of butterflies in the Peace region. Butterfly numbers are extremely variable from year to year and annual monitoring is required to properly assess the status of disjunct butterfly populations. Butterflies have been found to be the most dependant on prairie remnants of all insects (Panzer et al. 1995 cited in Debinski 1997) and butterflies, like birds, "are widely considered to be good indicators of the health of the environment" (Harding 1995). While a variety of insect species may be valuable as bio-indicators, the popularity and observability of butterflies makes them an excellent subject for habitat monitoring. The close association between the Peace region disjuncts and their habitat (including larval food plants, nectaring sources and microhabitats) makes these populations important indicators of ecological function in the remnant native grasslands.

Past butterfly information for the Peace region was collected by a small handful of individuals (primarily Bowman (1950), Llewllyn Jones (1951), Case and Bird (1977), and Kondla et al. (1994)), and few observations have been made since the mid-1980s. Historically sites were visited in four local areas, primarily near Fairview and Peace River, Alberta. In 2001, over one-third of these historic sites were revisited during the appropriate butterfly flight seasons and a number of additional sites were surveyed. 
In the 1980s, Dr. Felix Sperling (University of Alberta) conducted detailed taxonomic work on Alberta swallowtails (Sperling 1987) and he designated the Pike's Old World swallowtail, which is found only in the Peace parkland, as a subspecies of Papilio machaon. Kondla (1998 and pers. comm.) further recommends that the Peace Parkland populations of the plains skipper (Hesperia comma assiniboia), coral hairstreak (Satyrium titus), striped hairstreak (Satyrium liparops), northern checkerspot (Chlosyne palla), Alberta arctic (Oeneis alberta) and Uhler's arctic (Oeneis uhleri varuna) also be considered for subspecies designation. At least one specimen of each target species was collected during the 2001 field season for potential DNA analysis and it is hoped that some of the necessary physical and genetic taxonomy work will be initiated in $2002 / 2003$. There continues to be some confusion over nomenclature for some of these species so all names used in this report are from Layberry et al. (1998).

The Alberta Natural Heritage Information Centre (ANHIC) (2000) tracks six butterfly subspecies or populations because they are found only in the Peace River Parkland natural sub-region (plains skipper, Pike's Old World swallowtail, coral hairstreak, Gorgone checkerspot (Chlosyne gorgone carlota), northern checkerspot, and Alberta arctic). The current provincial status report (Anon. 2001) lists the Old World swallowtail, Gorgone checkerspot, and Alberta arctic as sensitive and the plains skipper, coral hairstreak, and the northern checkerspot as secure in Alberta. However, taxonomic differences between Peace region and southern populations as well as serious habitat pressure, point to the need for a more detailed population assessment for all these species. Guppy and Shepard (2001) list all of the above plus the Uhler's arctic as species of concern (Provincial Rank S3) in British Columbia due to limited distributions and disappearing habitat along adjacent stretches of the Peace River.

All of the butterfly populations surveyed during this study have very narrow geographic ranges and specific habitat requirements making them particularly susceptible to habitat loss. Sound management practices and more information on life history, distribution and abundance will be necessary to ensure the long-term survival of the Peace region's disjunct butterfly populations. 


\subsection{METHODS}

The primary objective of this study was to initiate the first systematic assessment of eight butterfly populations or subspecies of concern at previously known sites and to begin an inventory of new and potential sites. The plains skipper, Pike's Old World swallowtail, coral hairstreak, striped hairstreak, Gorgone checkerspot, northern checkerspot, Uhler's arctic and Alberta arctic were chosen for this year's survey based on preliminarily general status assessments and recommendations from primary researchers (Norbert Kondla, Dr. Ted Pike and Dr. Felix Sperling). The Alberta Natural Heritage Information Centre (ANHIC) (2001) provided historical occurrence information for all of the study butterflies except the Uhler's arctic. That data included detailed site information from the above researchers plus records from the literature and other known collections. Historic records for the Uhler's arctic are from Kondla et al (1994). In most cases, records are for adult butterflies but some records for Pike's Old World swallowtail include larva.

Sites extend from the Bear Canyon area near the British Columbia border, along the Peace River through Highland Park, Dunvegan and Green Island to the town of Peace River and north to the Manning area and La Crete (see Figure 1). There are also upland sites in the Sandhill Lake and Lac Cardinal areas near Fairview and in the Kleskun Hills east of Grande Prairie. The locations north of Peace River (Manning and La Crete) were not included in this year's survey due to time and travel constraints. In some cases, historical records gave only general site locations so access and the presence of suitable native grassland habitat were also considered when determining sites to visit.

As many sites as possible were visited during the flight season of each species. Observers walked the area and recorded all butterflies seen as well as weather conditions and total survey time. Surveys were not conducted on cloudy days. Every effort was made to assess suitable microhabitats within each area and these locations were searched more thoroughly. Striped and coral hairstreaks, for example, occur only in patches of saskatoon (Amelanchier alnifolia) and chokecherry (Prunus virginiana). These butterflies prefer to perch and considerable search effort is required to find even single individuals.

New sites for each species were discovered while visiting previously known locations as well as native grassland patches identified by the Peace Native Grassland Program. Some new sites were also located using aerial photography. Often sites known for one grassland species were found to support additional species during different seasons. Staff of the Peace Native Grasslands Program and an ANHIC survey of Artemisia dracunculus (larval food plant of the Pike's Old World swallowtail) recorded butterfly observations whenever possible and were able to add a number of upland sites plus three swallowtail sites to our inventory.

Adult butterflies were identified by sight, usually after capture with an insect net. On one occasion, larvae of the Pike's Old World swallowtail were also identified. At least one individual of each species was collected for possible future DNA analysis at the University of Alberta and for a reference collection being developed by Alberta Fish and 
Wildlife. Most sites were visited for one to two hours. All butterfly/site records will be submitted to the Alberta Natural Heritage Information Centre (ANHIC) and the Biodiversity/ Species Observation Database (BSOD). A CD-ROM containing the butterfly data, detailed site locations and photographs of the study sites was also produced.
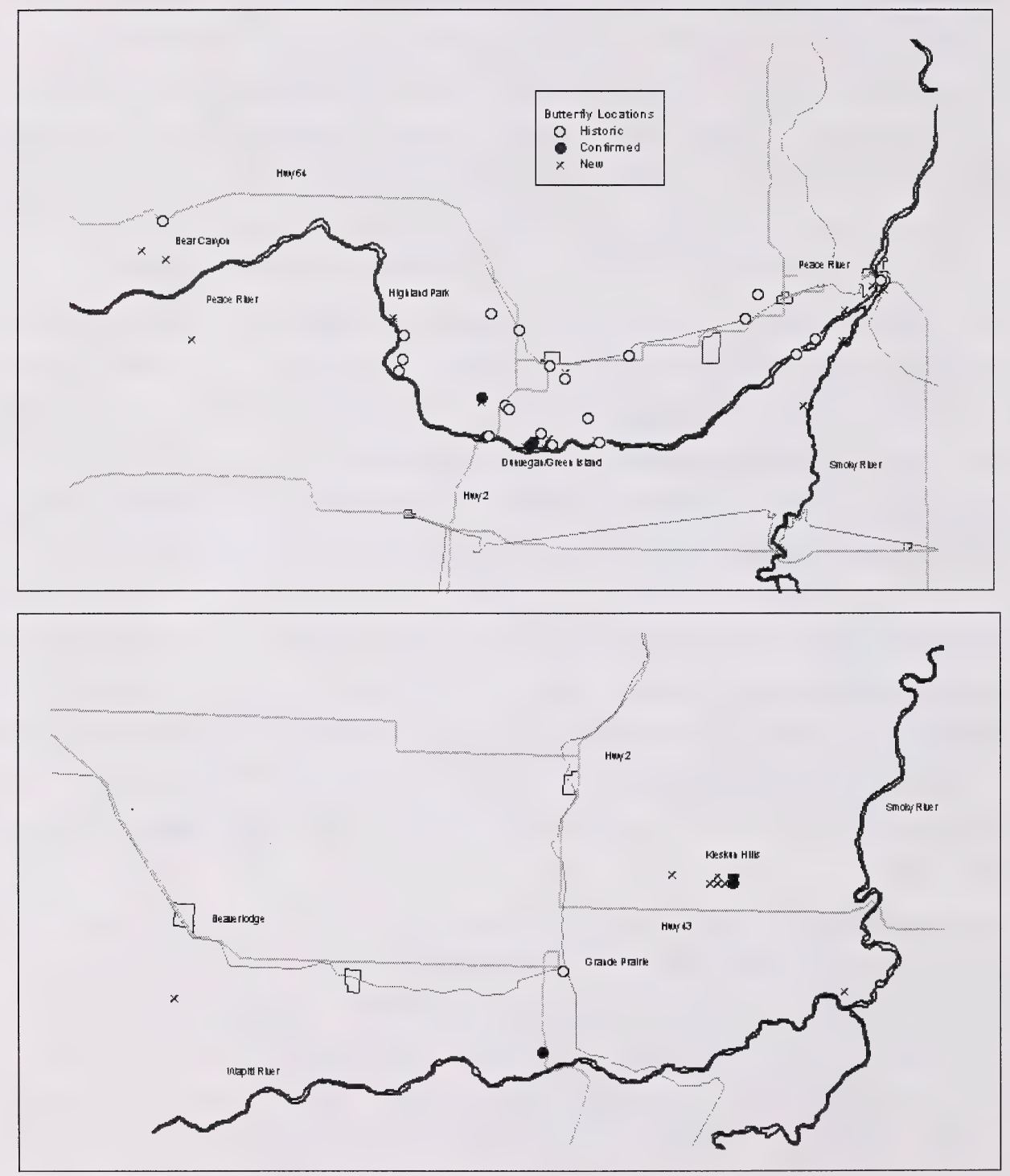

Figure 1. Map of historical and new records for south Peace disjunct butterflies. 


\subsection{RESULTS}

Between June $8^{\text {th }}$ and August $22^{\text {nd }}, 2001,26$ sites were visited at least once (Table 1). The sites have been grouped into four local areas containing individual sites found within about $20 \mathrm{~km}$ of each other. Since populations vary considerably from year to year, it is assumed that while the butterflies may continue to persist within a local area, they may not be found at each site each year. Of the 28 historical sites identified in the four local areas, 10 sites were visited. This represents $36 \%$ of the sites. In addition, 14 new sites were identified (a 50\% increase). Many historical site descriptions were rather general but every attempt was made to get as close as possible. Bear Canyon, for example, was listed as a historic site but without a specific location. Butterflies were found at three places in that vicinity but not necessarily at the historical site. Other sites, such as Sandhill Lake, appear to have experienced some forest re-growth since the 1980 s and may no longer be suitable for some butterfly species.

Site visits were included in Table 1 only if the butterfly was expected to be flying at the time of the visit. By the time fieldwork began, both the Alberta arctic and the Gorgone checkerspot had largely finished flying so fewer sites were verified for these species. The larvae of the Pike's Old World swallowtail can also be found in August but only one was found during this survey. Flight seasons for each of the target butterfly species (based on ANHIC records and study results) are illustrated in Figure 2.

Table 1. Survey locations and butterfly occurrence results by species.

Legend:

\begin{tabular}{|l|c|}
\hline Historical Sites & \\
\hline Butterfly recorded at site & $\mathbf{x}$ \\
\hline Butterfly not recorded at site & $\mathbf{0}$ \\
\hline Identification likely but not confirmed & $?$ \\
\hline Larvae recorded at site & $\mathbf{x l}$ \\
\hline
\end{tabular}

\begin{tabular}{|c|c|c|c|c|c|c|c|c|}
\hline & 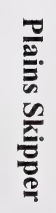 & 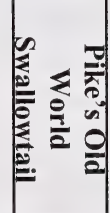 & 商 & 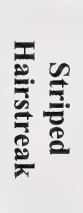 & 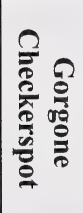 & 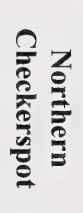 & 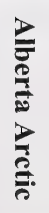 & 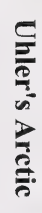 \\
\hline \multicolumn{9}{|l|}{ Fairview Area } \\
\hline $16 \mathrm{~km}$ southeast of Fairview & & $\mathrm{x}$ & $\mathbf{0}$ & $\mathrm{x}$ & & $\bar{x}$ & & $\mathrm{x} ?$ \\
\hline Green Island market & $\bar{x}$ & & & & & & & \\
\hline Green Island, water plant & $\mathbf{x}$ & & & & & & & \\
\hline East of water plant (two adjacent quarters) & & $\mathbf{x}$ & & & & & & \\
\hline Green Island, along road and riverbank & 0 & $\mathbf{x}$ & $\mathbf{x}$ & & & $\mathbf{0}$ & $\bar{E}$ & $\bar{x}$ \\
\hline \multicolumn{9}{|l|}{ Green Island, top of slope } \\
\hline \multicolumn{9}{|l|}{$12 \mathrm{~km}$ southwest of Friedenstal, } \\
\hline \multicolumn{9}{|l|}{ Fairview } \\
\hline Friedenstal & x? & & & & & & & \\
\hline $11 \mathrm{~km}$ south of Bluesky & & & & & & & & \\
\hline
\end{tabular}




\begin{tabular}{|c|c|c|c|c|c|c|c|c|}
\hline Dunvegan & 0 & $\mathrm{x}$ & o & 0 & 0 & o & $\mathbf{x}$ & $\mathbf{x}$ \\
\hline Fairview Ski Hill & $\mathbf{0}$ & $\mathrm{x}$ & & $\mathbf{x}$ & & o & & $\mathbf{x}$ \\
\hline Highland Park & & $\mathbf{x}$ & $\mathbf{0}$ & $\mathbf{x}$ & & o & - & $\mathbf{x}$ \\
\hline \multicolumn{9}{|l|}{$29 \mathrm{~km}$ west of Fairview (2 nearby quarters) } \\
\hline Sandhill Lake & & & & & & & & o \\
\hline \multicolumn{9}{|l|}{ Gage area } \\
\hline \multicolumn{9}{|l|}{$5 \mathrm{~km}$ southwest of Whitelaw } \\
\hline \multicolumn{9}{|l|}{ Peace River Area } \\
\hline \multicolumn{9}{|l|}{$3 \mathrm{~km}$ south of Lac Cardinal } \\
\hline \multicolumn{9}{|l|}{$5 \mathrm{~km}$ southwest of Lac Cardinal } \\
\hline \multicolumn{9}{|l|}{ Figure 8 Lake } \\
\hline \multicolumn{9}{|l|}{ Shaftsbury Ferry } \\
\hline \multicolumn{9}{|l|}{$6 \mathrm{~km}$ northeast of Shaftsbury } \\
\hline Lot 27 & & & & & & & $\mathbf{0}$ & $\mathbf{x}$ \\
\hline $\begin{array}{l}\text { Peace River town (including } 12 \mathrm{ft} \text { Davis } \\
\text { site) }\end{array}$ & o & $\bar{x}$ & & & & 0 & 0 & $\mathbf{x}$ \\
\hline Judah Hill & & $\mathrm{x}$ & & & & & & $\mathbf{x}$ \\
\hline Misery Mountain & & & & & & & & $\mathbf{x}$ \\
\hline Peace/Foster's Points & & $\mathbf{x}$ & & & & $\mathbf{x}$ & $\mathbf{x}$ & $\mathbf{x}$ \\
\hline Smokey Ridge 1 & & 0 & & & & $\mathbf{x}$ & & $\mathbf{0}$ \\
\hline Smokey Ridge 2 & & $\mathbf{0}$ & & & & 0 & & $\mathbf{x}$ \\
\hline Heart River ** & & $\mathbf{x}$ & & & & & & \\
\hline \multicolumn{9}{|l|}{ Bear Canyon Area } \\
\hline \multicolumn{9}{|l|}{ Clear River } \\
\hline \multicolumn{9}{|l|}{ Bear Canyon } \\
\hline Bear Canyon, ravine & & o & & & & & & $\mathbf{x}$ \\
\hline Bear Canyon, grazing Lease & & $\mathbf{x}$ & & & & & & \\
\hline Cherry Point ** & & $\mathbf{x l}$ & & & & & & \\
\hline \multicolumn{9}{|l|}{ Grande Prairie \& east } \\
\hline \multicolumn{9}{|l|}{ Grande Prairie } \\
\hline Kleskun Natural Area & $\mathrm{x}$ & 0 & $\mathbf{x}$ & $\mathbf{0}$ & & $\mathbf{0}$ & $\mathrm{x}$ & $\mathrm{x}$ \\
\hline Kleskun Corner* & $x$ & & & & & & & \\
\hline GP/Wapiti & $x$ & & & & & & & \\
\hline Smoky Ranch * & $\mathbf{x}$ & & & & & & & \\
\hline Kleskun Ranch * & $\mathbf{x}$ & & & & & & & \\
\hline Spring Creek Site * & & & $\mathbf{x}$ & & & & & \\
\hline \multicolumn{9}{|l|}{ Beaverlodge } \\
\hline Number of historic sites & 19 & 10 & 3 & 3 & 2 & 5 & 13 & 7 \\
\hline $\begin{array}{l}\text { Number of historic sites visited and } \\
\text { butterfly seen }\end{array}$ & 4 & 5 & $\mathbf{0}$ & 1 & $\mathbf{0}$ & 1 & 2 & 6 \\
\hline $\begin{array}{l}\text { Number of historic sites visited and } \\
\text { butterfly not seen }\end{array}$ & 3 & 1 & 1 & $\mathbf{0}$ & 1 & 3 & 1 & $\mathbf{0}$ \\
\hline $\begin{array}{l}\text { Total number of sites visited and } \\
\text { butterfly seen }\end{array}$ & 8 & 12 & 3 & 3 & 0 & 3 & 3 & 13 \\
\hline $\begin{array}{l}\text { Total number of sites visited and } \\
\text { butterfly not seen }\end{array}$ & 4 & 4 & 3 & 2 & 1 & 7 & 2 & 2 \\
\hline $\begin{array}{l}\text { Total number of local areas where } \\
\text { butterfly was seen }\end{array}$ & 2 & 3 & 2 & 1 & 0 & 2 & 3 & 4 \\
\hline
\end{tabular}




\begin{tabular}{|c|c|c|c|c|c|c|c|c|c|c|c|c|c|c|}
\hline & 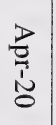 & 胥 & $\underset{\frac{1}{0}}{\stackrel{3}{0}}$ & 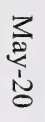 & 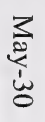 & $\frac{\grave{\vdots}}{\stackrel{1}{0}}$ & 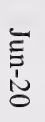 & 志 & $\frac{\grave{\Xi}}{0}$ & $\bar{\Xi}$ & 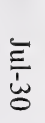 & $\stackrel{\substack{a \\
0}}{\frac{0}{0}}$ & 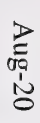 & 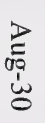 \\
\hline \multicolumn{15}{|l|}{ Plains Skipper } \\
\hline \multicolumn{15}{|c|}{$\begin{array}{l}\text { Pike's Old World } \\
\text { Swallowtail }\end{array}$} \\
\hline \multicolumn{15}{|l|}{ Coral Hairstreak } \\
\hline \multicolumn{15}{|c|}{ Striped Hairstreak } \\
\hline \multicolumn{15}{|l|}{$\begin{array}{l}\text { Gorgone } \\
\text { Checkerspot }\end{array}$} \\
\hline \multicolumn{15}{|l|}{$\begin{array}{l}\text { Northern } \\
\text { Checkerspot }\end{array}$} \\
\hline Uhler's Arctic & & & & & $=$ & & & & $=$ & & & & & \\
\hline Alberta Arctic & & & & & & & & & & & & & & \\
\hline
\end{tabular}

Figure 2. Flight times for Peace Region disjunct butterflies.

All of the survey populations except the plains skipper and the coral hairstreak were found associated only with native grassland slopes along the Peace and Smoky Rivers, along associated tributaries such as the Clear River and Hines Creek and on the eroded areas of Kleskun Hill. The plains skipper and the coral hairstreak were also found in upland areas of native grassland as well as on gently sloping native hillsides.

\section{$\underline{3.1 \text { Species Accounts }}$}

\subsubsection{Plains Skipper}

The plains skipper was found in native or near native grassland sites that supported porcupine and needle grasses (Stipa spp.). There were more historical sites identified for this species than any of the others (19 sites in four local areas). Four historical sites were visited in three local areas and the skipper was verified at two sites south of Fairview and two near Grande Prairie (Table 1). Three new sites were also identified by the Peace Native Grasslands Program. Unfortunately, the Bear Canyon area was not visited during the flight period of this butterfly. Over 10 individuals were found at Kleskun Hill Natural Area on one occasion but all other records were for one or two butterflies. The known flight period for the plains skipper in the Peace region is August 7-27.

\subsubsection{Pike's Old World Swallowtail}

The Pike's Old World swallowtail only occurs on steep, native grassland slopes where the larval food plant, Artemisia dracunculus, occurs (Bird et al. 1995). Males actively cruise ridge tops but speed and slope make the butterflies difficult to net. Larvae are 
conspicuous and can be found on food plants later in the summer. Ten historical sites were identified for Pike's Old World swallowtail in the four local areas and the butterfly was found 12 times in three local areas. Six of those locations were new sites. From one to seven individuals were recorded at any given location. The known flight period for the Pike's Old World swallowtail is May 24 - July 4.

\subsubsection{Coral Hairstreak}

Three coral hairstreaks were found on or immediately adjacent to clumps of saskatoon at native grassland sites. Like the plains skipper, it was found on upland sites as well as along river slopes. This hairstreak was previously recorded at only three sites in two local areas. The butterfly was verified south of Fairview and it was discovered at two new sites in the Kleskun Hill area. Coral hairstreaks can be found nectaring but, since they prefer to perch, this butterfly is often difficult to find. The known flight period for the coral hairstreak in the Peace region is June 28 - August 11.

\subsubsection{Striped Hairstreak}

Striped hairstreaks are found closely associated with clumps of saskatoon, chokecherry and spreading dogbane (Apocynum androsaemifolium). Only three historical sites in two local areas were identified for this species. The butterfly was confirmed south of Fairview and found at two new sites west of Fairview. Striped hairstreaks may be colonial (Acorn 1993) and prefer to perch, so they are difficult to survey. Three individuals were found flying together on one occasion but the other individuals were found singly after considerable searching time. The known flight period for the striped hairstreak in the Peace region is June 24 - July 25.

\subsubsection{Gorgone Checkerspot}

There are only two known locations for the Gorgone checkerspot in the Peace Region (Dunvegan and the grassy slopes above Green Island). Due to a late start on the field season and general site location information, neither colony was verified this year. The known flight season for the Gorgone checkerspot in the Peace region is May 17 - June 26.

\subsubsection{Northern Checkerspot}

Three northern checkerspots were found in, or at the edge of, native grassland on river slopes. Five historical sites from two local areas had been identified for this species and it was verified at one site south of Fairview and found at two new sites near Peace River. The known flight season for the northern checkerspot in the Peace region is June 11 July 4. 


\subsubsection{Alberta and Uhler's Arctic}

Both the Alberta and Uhler's arctic were found associated with native, grassy slopes. Males tend to congregate along ridge tops making them relatively easy to flush. Thirteen historic sites were identified for the Alberta arctic in three local areas but due to delays starting the field season the butterfly was only verified at one site in each local area. At least six individuals were seen on a single visit to Kleskun Hill Natural Area. The known flight season for the Alberta arctic in the Peace region is April 26 - June 9.

ANHIC has not begun to collect site information for the Uhler's arctic pending further taxonomic work on the Peace River population but Kondla et al. (1994) list seven historic sites. The butterfly was found at six of those sites plus seven new sites in all four local areas. Twenty-nine individuals were seen at Misery Mountain in Peace River on one occasion but usually five to ten butterflies were recorded at any given site. The known flight season for the Uhler's arctic in the Peace region is May 23 - July 2.

\subsection{DISCUSSION}

Butterfly species that are dependent on native grasses tend to only use non-agricultural sites; an association that is clearly affected by larval host plant requirements (Fleishman et al. 1999). This degree of habitat affinity is particularly significant for four of the eight current Peace region species of concern. The larvae of the plains skipper, Alberta arctic and Uhler's arctic feed on native grasses and larvae of the Pike's Old World swallowtail feed exclusively on a plant restricted to eroded native slopes (A. dracunculus). Fleishman et al. (1999) also found that the "species composition of butterflies was more diverse within non-agricultural sites than within agricultural sites". This was partly due to the greater diversity of vegetation in native sites; a feature that could further affect habitat affinity in the above species as well as in the checkerspots and hairstreaks. The "hilltopping" behaviour of Pike's Old World swallowtail, northern checkerspot, Alberta arctic and Uhler's arctic also indicates that these species are thinly dispersed (and possibly rare) since hill top sites are more exclusively used as territories by such species than those which are common or have dense populations concentrated in a small area (Guppy and Shepard 2001). The close relationship between the disjunct butterflies of the Peace region and the remnant native grassland warrants further consideration when looking at land management in the area.

Work by Launer and Murphy (1994) also indicates a strong correlation between the occurrence of a rare grassland butterfly in remnant native patches and distance from a single core population in a larger habitat area. This has important ramifications for the Peace region butterflies, since many of the remnant patches vary considerably in their distance from the core populations along the Peace River. It becomes more and more difficult for populations to re-colonize patches as the number of sites continues to dwindle. It is therefore important that patches found to be unoccupied during single-year 
surveys still be managed as potential sites as long as the primary habitat requirements of the butterflies still exist.

Annual variability is another factor that has a "significant effect on total butterfly abundance and evenness" (Fleishman et al. 1999; Launer and Murphy 1994). Weather conditions, over-wintering success and peculiarities of life cycle all affect the number of individuals and species found from one season to the next. These variables, in turn, affect the results of population surveys and speak for the need to monitor the same sites over a number of years.

Current land management of native grasslands within the Peace region falls under a number of different jurisdictions. Most of the slopes on the Peace River, as well as the valleys of the major tributaries, are crown lands managed by the Government of Alberta, with some small parcels being privately owned. The majority of the crown land on the north bank of the Peace, as well as some large sections on the south, has been leased to local landowners for grazing with monitoring carried out by the Public Lands Division. A few large stretches of the south bank plus some tributaries have been included in the newly designated Peace River and Dunvegan West Wildland Provincial Parks and Greene Valley Provincial Park which are administered by Parks and Protected areas. Remaining grasslands are being further fragmented through continued agricultural expansion and the sale of public land (A. Baker, Peace Native Grassland Program, pers. comm.). Land management is currently handled on a site by site basis and the Alberta Conservation Association (E. Kolodochuck, pers. comm.) has found numerous problems with over-utilization even on grazing leases with conservation notations. This speaks for the need to develop area-wide land use guidelines that stipulate requirements for maintaining diverse, natural grasslands.

One of the challenges in assessing the status of the Peace region's disjunct butterfly populations is the lack of detailed taxonomic work. P. machaon pikei was designated as a subspecies in the 1980s but work on the other populations is preliminary. Kondla (1998 and pers. comm.) indicates that subspecies designation is likely warranted for the plains skipper, coral hairstreak, striped hairstreak, northern checkerspot, Alberta arctic and Uhler's arctic. Kondla et al. (1994) and Guppy et al. (1994) also suggest that the garita skipperling (Oarisma garita), great spangled fritillary (Speyeria cybele pseudocarpenterii), aphrodite fritillary (Speyeria aphrodite manitoba) and common ringlet (Coenonympha tullia benjamini) may have disjunct, Peace region populations that warrant further study. Subspecies designation for the Peace region populations would add credence to habitat management programs but that does not absolve land managers of their existing responsibility to ensure the long-term survival of these disjunct populations. 


\section{$\underline{4.1 \text { Species Specific Management Considerations }}$}

\subsubsection{Plains Skipper}

The plains skipper is closely tied to remnant native grasslands with the larva feeding only on native prairie grasses (primarily spear, porcupine, needle grasses (Stipa spp.), June grass (Koeleria cristata) and blue grama (Bouteloua gracilis) (Layberry 1998)). Adults are often seen nectaring on composites. The range of the Peace region population extends along the Peace River from the canyon in British Columbia north to the Manning area (Bird et al. 1995; Guppy and Shepard 2001). This skipper also uses upland prairie sites around Fairview and Grande Prairie including native forest openings in a sand dune area along the Wapiti River. Alberta Fish and Wildlife (Anon. 2001) lists this species as "Secure", but the Peace region population is threatened with extirpation due to habitat loss and fragmentation. ANHIC ranks the Peace River population as S1S2 ${ }^{\prime}$. Given its association with upland native grassland patches, the plains skipper may be useful for habitat monitoring on these sites.

\subsubsection{Pike's Old World Swallowtail}

Pike's Old World swallowtail is only found along the Peace River and associated tributaries from British Columbia north to the Manning area (Bird et al. 1995; Guppy and Shepard 2001). The Old World swallowtail is currently listed as "Sensitive" by Alberta Fish and Wildlife (Anon., 2001). However, the Pike's sub-species may be at risk of extinction because of its restricted distribution, host plant specialization, and sensitivity to human activities. The Pike's sub-species is ranked as S1S2 by ANHIC and is on the intermediate priority candidate list for COSEWIC (unpublished report). The results of the survey of $A$. dracunculus currently being conducted by ANHIC will be valuable in assessing the potential range of Pike's Old World swallowtail along the Peace River. Even though the larval plant, $A$. dracunculus, can be found on overgrazed pasture as well as on dry eroded slopes, Bird et al. (1995) point out that the butterfly also requires nectar sources for feeding and high river banks as mate-finding sites. Diverse, native slopes therefore remain a primary requirement of this species.

\subsubsection{Coral Hairstreak}

The Peace region population of the coral hairstreak has been found along the Peace River and its tributaries from the Taylor area of British Columbia north to Paddle Prairie and La

\footnotetext{
' S- and G- ranks refer to sub-national (provincial) and global ranks, respectively. 1 indicates critically imperilled because of extreme rarity ( 5 or fewer occurrences, or very few remaining individuals), or because of some factor of its biology making it especially vulnerable to extinction. 2 indicates imperilled because of rarity (6-20 occurrences), or because of other factors demonstrably making it very vulnerable to extinction throughout its range. 3 indicates either very rare or local throughout its range, or found locally in a restricted range (21-100 occurrences). 4 indicates apparently secure, though it might be quite rare in parts of its range, especially at the periphery. 5 indicates demonstrably secure, through it may be quite rare in parts of its range, especially at the periphery.
} 
Crete (Bird et al. 1995; Guppy and Shepard 2001). New records were added during this survey in upland sites east of Grande Prairie. This butterfly is closely associated with patches of chokecherry and saskatoon on native prairie sites (both river slopes and upland). It is difficult to find unless nectaring and may be more common than current records indicate. A thorough survey of additional upland sites would be valuable for assessing the distribution of this species. This coral hairstreak is listed as "Secure" by Alberta Fish and Wildlife. The Peace region sub-species has a restricted distribution and is sensitive to habitat changes associated with several human activities. It is listed as S1S2 by ANHIC. The Peace region population is part of a sub-species pending further taxonomic study.

\subsubsection{Striped Hairstreak}

The taxonomy for this species remains unclear but Kondla et al. (1994) suggest that the Peace River population warrants subspecies designation. This butterfly has been recorded from the Taylor area of British Columbia north to the Manning area of Alberta (Bird et al. 1995; Guppy and Shepard 2001). The striped hairstreak is found almost exclusively in patches of saskatoon, chokecherry and spreading dogbane at the top of gullies or ravines (Bird et al. 1995). It prefers to perch and, like the coral hairstreak, may be more abundant than current records suggest. More survey work and information on habitat use is required for this species and the coral hairstreak. Alberta Fish and Wildlife currently list this species as "Status Undetermined" but ANHIC ranks the Peace River population as S1S2.

\subsubsection{Gorgone Checkerspot}

The Gorgone checkerspot is a grassland specialist that flies in prairies, open ridges, edges of agricultural areas and ditches. The Peace region population is represented by only two known colonies (both along the Peace River south of Fairview) (Bird et al. 1995). Because of its affinity to native prairie, this species is listed as "Sensitive" by Alberta Fish and Wildlife and as S2 by ANHIC. Further surveys of this species are required to properly assess its status in this region. 
The Peace region population of the northern checkerspot appears to prefer native prairie slopes adjacent to stands of deciduous forest. Fleishman et al. (1999) suggest that this species is adversely affected by agricultural activities in the Great Basin. Larval hosts include Aster spp., fleabane (Erigeron spp.) and other composites (Bird et al. 1994) and Kondla et al. (1994) suggest an association with spreading dogbane. The northern checkerspot can be found along the Peace River from the Peace Canyon of British Columbia to Fort Vermilion (Bird et al. 1995; Guppy and Shepard 2001). It is currently listed provincially as "Secure" by Alberta Fish and Wildlife. The Peace region population is threatened by agricultural expansion and is listed as S1S2 by ANHIC.

\subsubsection{Alberta Arctic}

The Alberta arctic is closely associated with dry, sandy areas of natural prairie (Bird et al. 1995; Layberry et al. 1998). It has been found along the Peace River and its tributaries from west of Fairview north to Peace River, as well as across the border in British Columbia (Bird et al. 1995; Guppy and Shepard 2001). However, because it flies so early in the spring, it may have been missed by observers in some areas of its range. The Alberta arctic is also found on grassy slopes in the Kleskun Hills and further surveys of other upland sites may expand the known range for this species. The species is currently listed as "Sensitive" by Alberta Fish and Wildlife and as S1S2 by ANHIC.

\subsubsection{Uhler's Arctic}

Like the Alberta arctic, the Uhler's Arctic is found on dry, grassy, native slopes. It will also use lightly grazed areas (Layberry 1998) but requires native grasses for egg laying and as larval food plants. The Peace region population of Uhler's arctic occurs from British Columbia north to the Manning area and on the top of the Kleskun Hills (Bird et al. 1995; Guppy and Shepard 2001). There are physical differences between this disjunct population and southern members of the varuna subspecies but until further taxonomic work is completed, ANHIC considers the sub-species "Secure". The Uhler's arctic is listed as a species of concern (S3) in the Peace Canyon of British Columbia, however, due to habitat loss and grazing (Guppy et al. 1994; Guppy and Shepard 2001).

\subsection{MANAGEMENT IMPLICATIONS AND FUTURE DIRECTION}

\section{$\underline{5.1 \text { Habitat Protection }}$}

Habitat loss (followed by widespread pesticide use) is the greatest threat facing butterfly populations (Guppy and Shepard 2001). Of the eight butterfly species surveyed during this project, six are being tracked at the population or sub-species level by ANHIC (2000) and Alberta Fish and Wildlife (unpublished data). Given the dependence of these 
butterflies on remnant native prairie, management plans must be developed that conserve native vegetation - both grasslands and associated saskatoon/chokecherry patches. For those species that lay their eggs on native grasses (plains skipper, Alberta arctic, Uhler's arctic), grazing during that season can have serious affects on population size (Guppy and Shepard 2001). Wherever possible, provincial land managers need to work with leaseholders to develop grazing plans that reflect the fragile nature of this grassland ecosystem and maintain the diversity of grassland vegetation.

Some native prairie has been protected through Alberta's Special Places program. The wildland provincial parks on the south side of the Peace include some native prairie habitat particularly around the confluence of the Smoky River and associated tributaries. Unfortunately, a number of large, provincial grazing leases were excluded from protection. Provincial natural areas at Dunvegan and Highland Park further protect small pieces of the slopes along the north bank. Protective notations should be placed on all crown land containing native grassland along the Peace River and its tributaries and every effort should be made to designate some of the grazing land on the north shore as Heritage Rangeland in an effort to standardize range management practices for these native slopes.

Support should continue for the Peace Native Grassland Program as it continues to identify upland sites in the Grande Prairie, Spirit River, Fairview and Peace River areas. Their proposed landowner stewardship program, including land management strategies for native grassland, will play an important role in conserving habitat for disjunct butterflies. Expansion of significant upland sites such as Kleskun Hill Natural Area would also be advantageous.

\section{$\underline{5.2 \text { Further Assessment of the Abundance and Distribution }}$ of Disjunct Butterflies in the Peace Grasslands}

Protection of disjunct butterflies through enhanced land management of the Peace River grasslands is contingent upon better information regarding the distribution, abundance and life histories of the butterflies of concern. Additional surveys are required to firmly establish the distribution of the Peace region disjuncts and to begin assessing abundance over time. More detailed information regarding larval food plants and adult nectaring sources would also be useful for habitat delineation. The garita skipperling should be added to the list for future monitoring since it is also dependant on native grasslands and appears to have a disjunct population in the Peace region (Kondla et al. 1994; Guppy et al. 1994). Surveyors should also watch for the small wood-nymph (Cercyonis oetus) since it occurs as a disjunct population in dry grasslands along the Peace River in British Columbia but has yet to be recorded in northwestern Alberta (Bird et al. 1995; Guppy and Shepard 2001). 


\subsubsection{Abundance}

Fixed transect surveys, following the method developed by Pollard (1977), should be established for each Peace region local area as outlined in Appendix I. Such surveys would "provide quantitative information on the fluctuations of butterfly numbers from year to year, so that any underlying trends can be assessed" (Harding et al. 1995). These surveys could also provide additional information on habitat and microhabitat associations particularly if flowering plant surveys were included. Upland and river break transects should be established on both grazed and un-grazed sites in order to assess the affect of such activities on the abundance of grassland dependant butterflies.

\subsubsection{Distribution}

Further effort is required to verify the known ranges of the Peace region grassland butterfly populations and to identify additional new locations. The ANHIC Artemesia survey will be valuable in identifying sites for the Pike's Old World swallowtail as well as potential habitat for the arctics and the northern checkerspot. The Peace Native Grasslands Program will continue to provide candidate upland sites and to assist with butterfly observations. Very little work has been done near the British Columbia border or north of Peace River during the flight seasons of all the butterflies. Aerial photos and mapping work done by ANHIC also indicate the potential for additional sites along the Smoky and Wapiti Rivers, other major tributaries of the Peace and the Hay Lakes area.

\section{$\underline{5.3 \text { Clarification of Taxonomy }}$}

Detailed physical and genetic taxonomy work is urgently needed to confirm subspecies status. Specimens collected during this field season have been passed on to the University of Alberta for possible future DNA analysis. Support should be given to researchers to begin the necessary taxonomic studies.

\section{$\underline{5.4 \text { Status Recommendations }}$}

All of the populations surveyed in this study have been ranked by ANHIC as S1S2 except the Gorgone checkerspot (S2) and the Uhler's arctic. Unpublished data from Alberta Fish and Wildlife further suggests that the Pike's Old World swallowtail and plains skipper may be at risk and that the other populations (excluding the Uhler's arctic) are sensitive (Alberta Fish and Wildlife does not provide formally status designations for sub-species or populations). Unless additional surveying indicates substantial increases in abundance and distribution for these butterflies, those rankings appear to be appropriate. A review of the literature further indicates that the Uhler's arctic warrants consideration as a disjunct population worthy of sub-species status. In light of the physical differences described and the narrow, native grassland-dependant range of the Peace region population, it is recommended that this population also be considered sensitive (S2). As 
mentioned previously, additional surveying may also indicate the need to track the Peace region population of the garita skipperling separately as well.

\section{$\underline{5.5 \text { Public Education }}$}

An education program should be implemented in an effort to increase public awareness of the significance of the remnant grasslands of the Peace region and their associated flora and fauna. Landowner stewardship programs such as that being initiated by the Peace Native Grassland Program should be expanded to include grasslands along the slopes of the Peace River and its tributaries. Efforts are also underway within the naturalist community to establish a provincial database for butterfly records to compliment existing bird and plant programs. This would increase public awareness of butterflies and provide additional information on butterfly distribution and abundance. 


\subsection{LITERATURE CITED}

Acorn, John. 1993. Butterflies of Alberta. Lone Pine Publishing, Edmonton, Canada.

Alberta Natural Heritage Information Centre. April 2000. URL:

http://www3.gov.ab.ca/env/parks/anhic/buttertrack.html and

http://www3.gov.ab.ca/env/parks/anhic/butterwatch.html. Parks and Protected Areas Division, Alberta Community Development.

Alberta Natural Heritage Information Centre. 2001. Data files for butterflies and skippers. Parks and Protected Areas Division, Alberta Community Development.

Anonymous. 2001. The General Status of Alberta Wild Species 2000. Alberta Fish and Wildlife, Sustainable Resource Development, Edmonton. URL: http://www3.gov.ab.ca/srd/fw/status/index.html

Bird, C.D., G.J. Hilchie, N.G. Kondla, E.M. Pike and F.A.H. Sperling. 1998. Alberta Butterflies. The Provincial Museum of Alberta, Edmonton, Canada.

Bowman, K. 1950. An Annotated List of the Lepidoptera of Alberta. Canadian Journal of Zoology 29:121-165.

Case, J.W. and C.D. Bird. 1977. Butterflies and Skippers of West-central Alberta. Blue Jay 35(4):208-219.

COSEWIC. 2001. URL: http://www.speciesatrisk.gc.ca/sar/main.htm

Debinski, D.M. and A.M.Babbit. 1997. Butterfly Species in Native Prairie and Restored Prairie. Prairie Naturalist 29:219-227.

Fleishman, E., G.T.Austin, P.F. Brussard and D.D. Murphy. 1999. A comparison of butterfly communities in native and agricultural riparian habitats in the Great Basin, USA. Biological Conservation 89:209-218.

Guppy C.S. and J.H. Shepard. 2001. Butterflies of British Columbia. UBC Press, Vancouver, B.C.

Guppy, C.S., J.H. Shepard, and N.G. Kondla. 1994. Butterflies and skippers of conservation concern in British Columbia. Canadian Field Naturalist 108:31-40.

Harding, P.T., J. Asher and T.J. Yates. 1995. Butterfly monitoring 1-recording the changes. In Ecology and Conservation of Butterflies. A.S. Pullin, editor. Chapman \&Hall, London, UK. Pages 3-22. 
Kondla, N. G. 1998. Alberta Butterflies of Conservation Interest: An Overview. Report for Alberta Natural Heritage Information Centre. Alberta Community Development.

Kondla, N.G., E.M. Pike and F.A.H. Sperling. 1994. Butterflies of the Peace River Region of Alberta and British Columbia. Blue Jay 52(2):71-90

Launer, A.E., Murphy, D.D. 1994. Umbrella species and the conservation of habitat fragments: a case of a threatened butterfly and a vanishing grassland ecosystem. Biological Conservation 69:145-153

Layberry, R.A., P.W. Hall and J.D. Lafontaine. 1998. The Butterflies of Canada. University of Toronto Press, Toronto, Canada.

Llewellyn-Jones, J.R.J. 1951 . An annotated check list of the macrolepidoptera of British Columbia. Ent. Soc. of British Columbia, Occasional Paper No. 1. 148pp.

Pollard, E. 1977. A method for assessing changes in the abundance of butterflies. Biological Conservation 12:115-134.

Sperling, F.A.H. 1987. Evolution of the Papilio machaon species group in western Canada (Lepidoptera:Papilionidae). Quaestiones Entomologicae 23:198-315.

Wilkinson, K. 1981. Remnant and early settlement prairies and solonetzic soils in the Peace River district. Masters Thesis, University of Calgary. 


\section{APPENDIX A. PROPOSED METHODS FOR FIXED TRANSECT MONITORING}

After Harding et al. 1995 and Pollard 1977

Fixed routes are established at each survey location. Transects are divided into sections representing different habitat types and can follow existing paths or be marked out using flags or GPS. Routes should take from one to two hours to complete.

Routes are walked once a week from mid-April until early September.

All butterflies seen within 5 meters of the route are recorded.

Walks are carried out between 11:00 a.m. and 3:30 p.m.

Minimum weather conditions should be established (Pollard only conducted counts when the temperature was from $13 \mathrm{C}-17 \mathrm{C}$ if there was $60 \%$ sunshine or more. Above $17 \mathrm{C}$, sunny or cloudy conditions were acceptable. Wind speed can also be a significant factor, particularly at exposed sites)

Records should include:

1. Duration of visit

2. Weather conditions

3. Notes on significant changes in habitat, management use etc.

4. Absences of species that should be expected when searched for during the appropriate season under ideal weather conditions

5. Evidence of breeding based on early breeding stages (eggs, larvae, pupa) 


\section{List of Titles in This Series}

(as of May 2002)

No. 1 Alberta species at risk program and projects 2000-2001, by Alberta Sustainable Resource Development, Fish and Wildlife Division. (2001)

No. 2 Survey of the peregrine falcon (Falco peregrinus anatum) in Alberta, by R. Corrigan. (2001)

No. 3 Distribution and relative abundance of the shortjaw cisco (Coregonus zenithicus) in Alberta, by M. Steinhilber and L. Rhude. (2001)

No. 4 Survey of the bats of central and northwestern Alberta, by M.J. Vonhof and D. Hobson. (2001)

No. 52000 survey of the Trumpeter Swan (Cygnus buccinator) in Alberta, by M.L. James and A. James. (2001)

No. 6 2000/2001 Brassy Minnow inventory at Musreau Lake and outlet, by T. Ripley. (2001)

No. 7 Colonial nesting waterbird survey in the Northwest Boreal Region - 2000, by M. Hanneman and M. Heckbert. (2001)

No. 8 Burrowing owl trend block survey and monitoring - Brooks and Hanna areas, by D. Scobie and R. Russell. (2000)

No. 9 Survey of the Lake Sturgeon (Acipenser fulvescens) fishery on the South Saskatchewan River, Alberta (June-September, 2000), by L.A. Winkel. (2000)

No. 10 An evaluation of grizzly bear-human conflict in the Northwest Boreal Region of Alberta (19912000) and potential mitigation, by T. Augustyn. (2001)

No. 11 Harlequin duck monitoring in the Northern East Slopes of Alberta: 1998-2000 preliminary results, by J. Kneteman and A. Hubbs. (2000)

No. 12 Distribution of selected small mammals in Alberta, by L. Engley and M. Norton. (2001)

No. 13 Northern leopard frog reintroduction. Raven River - Year 2 (2000), by K. Kendell. (2001)

No. 14 Cumulative effects of watershed disturbances on fish communities in the Kakwa and Simonette watersheds. The Northern Watershed Project. Study 3 Progress report, by T. Thera and A. Wildeman. (2001)

No. 15 Harlequin duck research in Kananaskis Country in 2000, by C.M. Smith. (2001)

No. 16 Proposed monitoring plan for harlequin ducks in the Bow Region of Alberta, by C.M. Smith. (2001)

No. 17 Distribution and relative abundance of small mammals of the western plains of Alberta as determined from great horned owl pellets, by D. Schowalter. (2001)

No. 18 Western blue flag (Iris missouriensis) in Alberta: a census of naturally occurring populations for 2000, by R. Ernst. (2000)

No. 19 Assessing chick survival of sage grouse in Canada, by C.L. Aldridge. (2000)

No. 20 Harlequin duck surveys of the Oldman River Basin in 2000, by D. Paton. (2000) 
No. 21 Proposed protocols for inventories of rare plants of the Grassland Natural Region, by C. Wallis. (2001)

No. 22 Utilization of airphoto interpretation to locate prairie rattlesnake (Crotalus viridis viridis) hibernacula in the South Saskatchewan River valley, by J. Nicholson and S. Rose. (2001)

No. 23 2000/2001 Progress report on caribou research in west central Alberta, by T. Szkorupa. (2001)

No. 24 Census of swift fox (Vulpes velox) in Canada and Northern Montana: 2000-2001, by A.

Moehrenschlager and C. Moehrenschlager. (2001)

No. 25 Population estimate and habitat associations of the long-billed curlew in Alberta, by E.J. Saunders. (2001)

No. 26 Aerial reconnaissance for piping plover habitat in east-central Alberta, May 2001, by D.R.C. Prescott. (2001)

No. 27 The 2001 international piping plover census in Alberta, by D.R.C. Prescott. (2001)

No. 28 Prairie rattlesnake (Crotalus viridis viridis) monitoring in Alberta - preliminary investigations (2000), by S.L. Rose (2001)

No. 29 A survey of short-horned lizard (Phrynosoma hernandesi hernandesi) populations in Alberta, by J. James (2001)

No. 30 Red-sided garter snake (Thamnophis sirtalis parietalis) education and relocation project - final report, by L. Takats (2002)

No. 31 Alberta furbearer harvest data analysis, by K.G. Poole and G. Mowat (2001)

No. 32 Measuring wolverine distribution and abundance in Alberta, by G. Mowat (2001)

No. 33 Woodland caribou (Rangifer tarandus caribou) habitat classification in northeastern Alberta using remote sensing, by G.A. Sanchez-Azofeifa and R. Bechtel (2001)

No. 34 Peregrine falcon surveys and monitoring in the Parkland Region of Alberta, 2001, by R. Corrigan (2002)

No. 35 Protocol for monitoring long-toed salamander (Ambystoma macrodactylum) populations in Alberta, by T. Pretzlaw, M. Huynh, L. Takats and L. Wilkinson (2002)

No. 36 Long-toed salamander (Ambystoma macrodactylum) monitoring study in Alberta: summary report 1998-2001, by M. Huynh, L. Takats and L. Wilkinson (2002)

No. 37 Mountain plover habitat and population surveys in Alberta, 2001, by C. Wershler and C. Wallis (2002)

No. 38 A census and recommendations for management for western blue flag (Iris missouriensis) in Alberta, by R. Ernst (2002)

No. 39 Columbian mountain amphibian surveys, 2001, by D. Paton (2002)

No. 40 Management and recovery strategies for the Lethbridge population of the prairie rattlesnake, by R. Ernst (2002) 
No. 41 Western (Aechmophorus occidentalis) and eared (Podiceps nigricollis) grebes of central Alberta: inventory, survey techniques and management concerns, by S. Hanus, H. Wollis and L. Wilkinson (2002)

No. 42 Northern leopard frog reintroduction - year 3 (2001), by K. Kendell (2002)

No. 43 Survey protocol for the northern leopard frog, by K. Kendell (2002)

No. 44 Alberta inventory for the northern leopard frog (2000-2001), by K. Kendell (2002)

No. 45 Fish species at risk in the Milk and St. Mary drainages, by RL\&L Environmental Services Ltd. (2002)

No. 46 Survey of the loggerhead shrike in the southern aspen parkland region, 2000-2001, by H. Kiliaan and D.R.C. Prescott (2002)

No. 47 Survey of native grassland butterflies in the Peace parkland region of northwestern Alberta - 2001, by M. Hervieux (2002)

No. 48 Caribou range recovery in Alberta: 2001/02 pilot year, by T. Szkorupa (2002)

No. 49 Peace parkland native grassland stewardship program 2001/02, by A. Baker (2002)

No. 50 Carnivores and corridors in the Crowsnest Pass, by C. Chetkiewicz (2002) 
. 


National Library of Canada
Bibliothèque nationale du

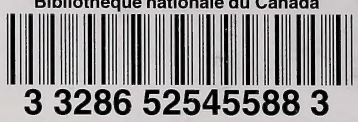

